\title{
Antarctic sea-ice extents and concentrations: comparison of satellite and ship measurements from International Polar Year cruises
}

\author{
Burcu OZSOY-CICEK, ${ }^{1}$ Stephen F. ACKLEY, ${ }^{1}$ Anthony WORBY, ${ }^{2}$ Hongjie XIE, ${ }^{1}$ \\ Jan LIESER ${ }^{2}$ \\ ${ }^{1}$ Department of Geological Sciences, University of Texas at San Antonio, One UTSA Circle, San Antonio, TX 78249, USA \\ E-mail: burcu@drcicek.com \\ ${ }^{2}$ Australian Antarctic Division and Antarctic Climate and Ecosystems CRC, Box 252-80, Hobart, Tasmania 7001, Australia
}

\begin{abstract}
Antarctic Sea Ice Processes and Climate (ASPeCt) ship-based ice observations, conducted during the Sea Ice Mass Balance in the Antarctic (SIMBA) and Sea Ice Physics and Ecosystem eXperiment (SIPEX) International Polar Year (IPY) cruises (September-October 2007), are used to validate remote-sensing measurements of ice extent and concentration. Observations include varied sea-ice types at and inside the ice edge of West $\left(\sim 90^{\circ} \mathrm{W}\right)$ and East $\left(\sim 120^{\circ} \mathrm{E}\right)$ Antarctica. Time series of Advanced Microwave Scanning Radiometer-Earth Observing System (AMSR-E) ice extents and US National Ice Center (NIC) ice edges were obtained for the 2007-08 periods bracketing the period these cruises were conducted. A comparison between passive microwave satellite imagery and ASPeCt observations of sea-ice concentration during two cruises was also performed. In $90^{\circ} \mathrm{W}$ regions, the concentrated pack ice indicated good correlation between ship observations and passive microwave estimates of the ice concentration $\left(R^{2}=0.80\right)$. In the marginal zone of West Antarctica and over nearly the entire sea-ice zone of East Antarctica, correlation dropped to $R^{2}<0.60$. These findings are consistent with other studies comparing passive microwave and ship observations and further verify that the East Antarctic sea-ice zone is more marginal in character. There are significant ice-edge differences between AMSR-E and NIC between late November 2007 and early March 2008 such that the AMSR-E sea-ice extent estimate is $1-2 \times 10^{6} \mathrm{~km}^{2}$ less than the NIC estimate.
\end{abstract}

\section{INTRODUCTION}

Extent and concentration of sea ice in the Earth's polar regions are sensitive indicators of global climate change (Turner and others, 2009). Sea-ice spatial extent can change rapidly in response to weather and ocean dynamics (Zhang, 2007). Sea-ice extent is also used as an input to global weather and climate models. Current climate models (Solomon and others, 2007) suggest that global warming will be felt most acutely in the polar regions. Even though sea-ice cover in both hemispheres is expected to respond to climate change, there are important differences between the northern and southern polar oceans which affect the sea-ice properties (Worby and Comiso, 2004). Antarctica is more complex in terms of its geography. For satellite analyses, it is divided into five sea-ice sectors (Fig. 1): the Weddell Sea $\left(60^{\circ} \mathrm{W}-20^{\circ} \mathrm{E}\right)$, the Indian Ocean $\left(20-90^{\circ} \mathrm{E}\right)$, the Pacific Ocean $\left(90-160^{\circ} \mathrm{E}\right)$, the Ross Sea $\left(160^{\circ} \mathrm{E}-130^{\circ} \mathrm{W}\right)$ and the Bellingshausen/Amundsen Seas (130-60 W) (Gloersen and others, 1992). Each sector has different climatic characteristics and the vast majority of Antarctic sea ice is snowcovered even in summer (Brandt and others, 2005). In contrast, the summer Arctic pack has bare ice and melt ponds. Therefore it is more difficult to draw a general picture of the entire Antarctic sea-ice trend and how it is responding to climate patterns.

Remote-sensing technology has provided a consistent record of sea ice since 1979 for both the Arctic and the Antarctic (Cavalieri and Parkinson, 2008; Parkinson and Cavalieri, 2008). Researchers have utilized satellite measurements to study changes in Arctic and Antarctic sea ice (Comiso and others, 1992; Gloersen and others, 1992;
Zwally and others, 2002; Cavalieri and others, 2003; Kwok and others, 2007; D.J. Cavalieri and others, http://nsidc.org/ data/nsidc-0051.html). Parameters like sea-ice cover and sea-ice extent are monitored (Worby and Comiso, 2004; Lubin and Massom, 2006) using satellite sensors that observe microwave radiation emitted from the ice surface. Satellite passive microwave data indicate that between 1979 and 2006 the annual average sea-ice extent in the Arctic decreased by $3.7 \%(10 \mathrm{a})^{-1}$ (Parkinson and Cavalieri, 2008). Decline in Arctic ice extent is occurring in every geographic area, in every season and in every month. Unlike the Arctic, where the decreasing trend is consistent, the Antarctic picture is more complex and sea-ice trends are smaller (Cavalieri and others, 2003; Liu and others, 2004). Between 1979 and 2008, the total annual Antarctic sea-ice extent increased by about $1 \%(10 \mathrm{a})^{-1}$. However the increase is not consistent and the sea-ice extent trend varies for all five sectors (Ross Sea, Bellingshausen/Amundsen Seas, Weddell Sea, Indian Ocean and Pacific Ocean) and all seasons (Cavalieri and Parkinson, 2008). Based on Cavalieri and Parkinson (2008) the annual trend of four individual sea-ice sectors indicated a small positive trend. However, of these, only the Ross Sea sector indicated a statistically significant increase (at the 95\% level), while the decrease in the Bellingshausen/Amundsen Seas was also statistically significant (at the $99 \%$ level).

Measurements of sea-ice physical properties are essential for understanding the role of the polar regions in global climate and oceanography, as the Antarctic sea-ice area at maximum extent covers larger areas than either the Antarctic continent or the Arctic sea-ice cover at its maximum. 

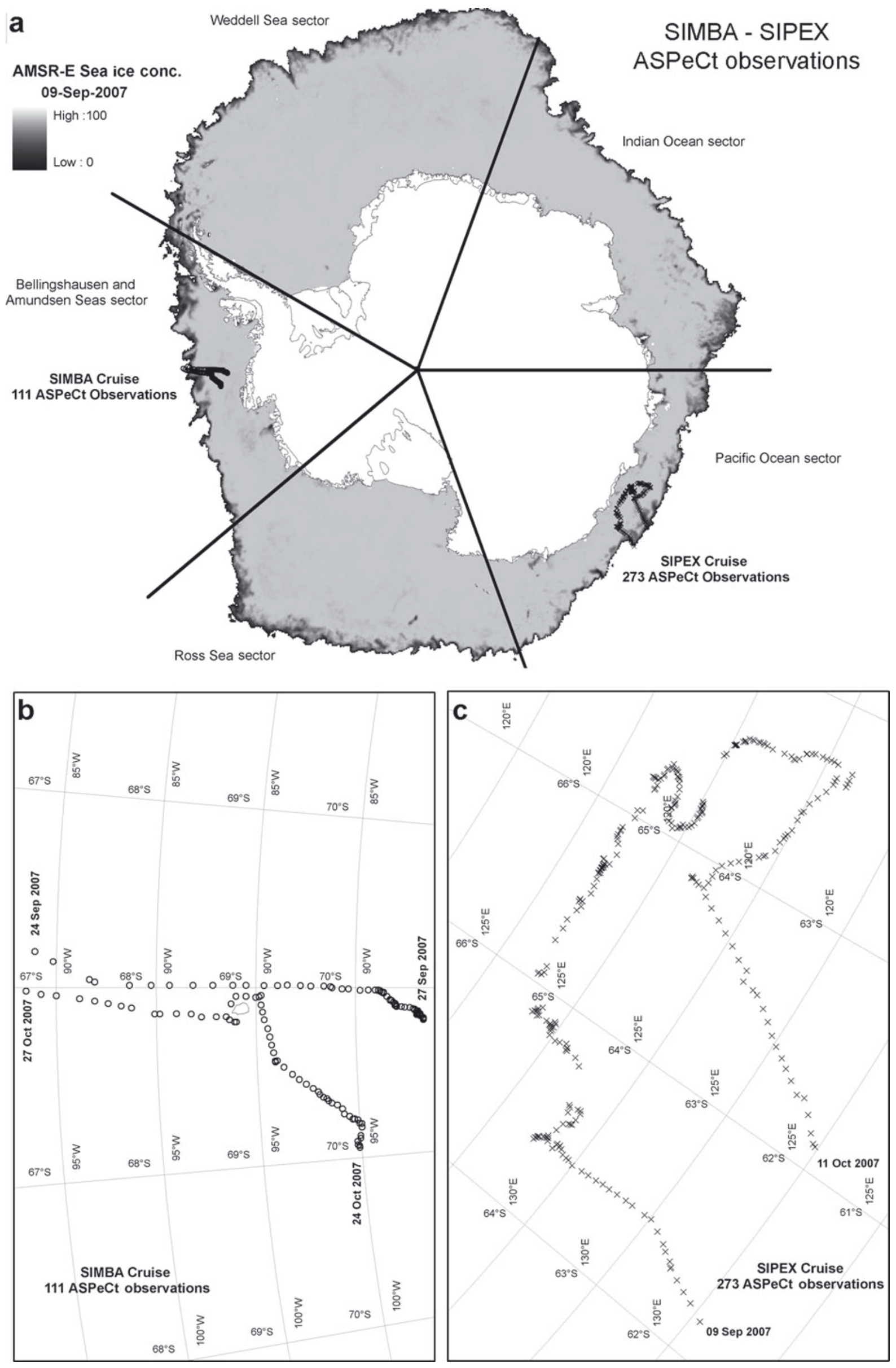

Fig. 1. (a) AMSR-E sea-ice concentration map on 9 September 2007. The sectors used for passive microwave analyses are shown. (b) Track of SIMBA cruise and ASPeCt observations between 24 September and 27 October 2007. (c) Track of SIPEX Cruise and ASPeCt observations between 9 September and 11 October 2007. 
During the International Polar Year (IPY) 2007-08, two Antarctic cruises conducted sea-ice surveys concurrently: one was the Sea Ice Mass Balance in the Antarctic (SIMBA) cruise in the Bellingshausen Sea at $\sim 90^{\circ} \mathrm{W}$ longitude and the other was the Sea Ice Physics and Ecosystem eXperiment (SIPEX) cruise in the 116-129 E longitudes off East Antarctica (Pacific sector). In this study, first, the total sea-ice cover around the entire continent was determined for 200708 from Advanced Microwave Scanning Radiometer-Earth Observing System (AMSR-E) passive microwave and US National Ice Center (NIC) ice-edge data. Second, Antarctic Sea Ice Processes and Climate (ASPeCt) ship observations from the SIMBA and SIPEX expeditions in the austral end of winter/beginning of spring 2007 are used as ground truth to verify the AMSR-E sea-ice concentration product provided by both the Enhanced NASA Team Algorithm (NT2) and Bootstrap Basic Algorithm (BBA).

\section{METHODOLOGY}

\section{Study area and ASPeCt in situ observations}

SIMBA and SIPEX were two IPY Antarctic sea-ice cruises in the Bellingshausen Sea and Pacific Ocean, respectively (Fig. 1). The SIMBA cruise aboard the R/V Nathaniel $B$. Palmer (NBP0709) began on 1 September 2007 and ended on 31 October 2007 in Punta Arenas, Chile. The SIPEX cruise aboard R/V Aurora Australis began on 5 September 2007 and ended on 16 October 2007 in Hobart, Tasmania. During almost 2 months at sea, sea-ice properties such as temperature, snow depth, ice thickness, meteorological conditions and ice biogeochemistry and biology were sampled to investigate sea-ice processes. The research cruises were part of a larger coordinated program designed to estimate the exchange of salt, fresh water and heat between the atmosphere and ocean, to characterize the thickness and extent of sea ice and to determine if the sea ice is changing in the study regions (Lewis and others, in press, Ozsoy-Cicek and others, in press, Weissling and others, in press, Worby and others, in press, Xie and others, in press). Additional ship-based observations on sea-ice morphology and distribution were conducted on R/Vs Nathaniel B. Palmer and Aurora Australis. The protocol used was devised by the ASPeCt expert group on multidisciplinary Antarctic sea-ice zone research within the Scientific Committee on Antarctic Research (SCAR) Physical Sciences program. ASPeCt ship-based visual observations entailed recording sea-ice conditions from the ship bridge every hour (Worby and Allison, 1999; www.aspect.aq). The observations included the record of overall sea-ice concentration and partial sea-ice concentration of the primary, secondary (if any) and tertiary (if any) ice types at each observation. For each ice type the overall concentration, ice thickness, floe size, topography, snow cover and snow depth were estimated. The air/water temperatures, wind speed and direction were also recorded from the vessel's underway data acquisition system.

During the SIMBA cruise, ice observations were conducted from 24 to 27 September 2007 upon entering into the ice edge in the Bellingshausen Sea and upon departure from 24 to 27 October 2007. From 28 September to 23 October 2007 the ship was moored to the same floe for the ice station Belgica studies, so no ice observations were taken. Therefore, 111 ASPeCt observations (Fig. 1) were obtained: 52 inbound observations collected between 24 and 27 September 2007 and 59 outbound observations collected between 24 and 27 October 2007 (Xie and others, in press). During the SIPEX cruise, the set of ice observations was collected continuously when the ship was moving from 9 September to 11 October 2007 upon entering and then departing the ice edge in the Pacific Ocean sector. A total of 273 ASPeCt observations (Fig. 1) was made.

For each study, one region was identified as the marginal ice zone and another was identified as the inner pack-ice zone. Specific criteria (e.g. change from low concentration $(0-50 \%)$ to stable high concentration $(90-100 \%)$ and from thin ice types (brash, nilas) to thick ice types (first year and thicker)), were used as the boundary between the marginal ice zone and inner pack-ice zone in both regions. For the SIMBA cruise, 29 observations (the first 11 observations on 24 and 25 September along the inbound track and the last 18 observations on 26 and 27 October along the outbound track; see Fig. 1) were identified as in the marginal ice zone, and 82 observations were identified in the inner pack-ice zone. For the SIPEX cruise, 29 observations (the first 9 observations on 9 and 10 September and the last 20 observations on 10 and 11 October; see Fig. 1) were identified as in the marginal ice zone and 244 observations were identified in the inner pack-ice zone.

\section{AMSR-E sea-ice concentration}

The AMSR-E on NASA's Aqua satellite provides passive microwave data to study the Earth's atmospheric, oceanic, cryospheric and land processes. Data include horizontally and vertically polarized brightness temperature $(\mathrm{Tb})$ from 6.9, 10.7, 18.7, 23.8, 36.5 and $89 \mathrm{GHz}$ frequencies. AMSRE/Aqua daily L3 sea-ice concentration polar grids are used for this study, where the spatial resolution of the data (pixel size) is $12.5 \mathrm{~km} \times 12.5 \mathrm{~km}$ (Comiso and others, 2003). The sea-ice concentration product represents the coverage of a unit area with sea ice. It is expressed in percent of the unit area, i.e. $0 \%$ means the area is totally covered by open water and $100 \%$ means that the area is totally covered by sea ice. The principal Antarctic sea-ice concentration in this product is derived by using the NT2 algorithm (Markus and Cavalieri, 2000). The same product also provides sea-ice concentration difference between the BBA (Comiso 1995) and NT2 (BBA - NT2). The main difference between the NT2 algorithm and the BBA is that the NT2 uses a wider range of frequencies to overcome the problem of detecting low sea-ice concentration values where the signatures of open water and ice-covered surfaces are virtually identical (Comiso and others, 2003). The NT2 algorithm uses the 18.7 GHz channels (vertical and horizontal polarization) together with the $36.5 \mathrm{GHz}$ channel at vertical polarization to calculate the total and partial (first-year ice and multi-year ice) ice concentration. Aditionally, it uses the $89.0 \mathrm{GHz}$ channel at vertical polarization to mitigate the influence of ice layers buried in the snow cover on the ice concentration retrieval (Parkinson and Comiso, 2008). However, as noted by Massom and others (1999) and Markus and Cavalieri (2000), both algorithms have difficulty recognizing the areas of either new ice or low sea-ice concentrations.

AMSR-E sea-ice concentration data were acquired for the 2007 winter period and the 2008 summer period to estimate sea-ice coverage during and after the SIMBA and SIPEX cruises. First, daily AMSR-E images between 1 August and 31 December 2007 and 1 January and 11 March 2008 were 


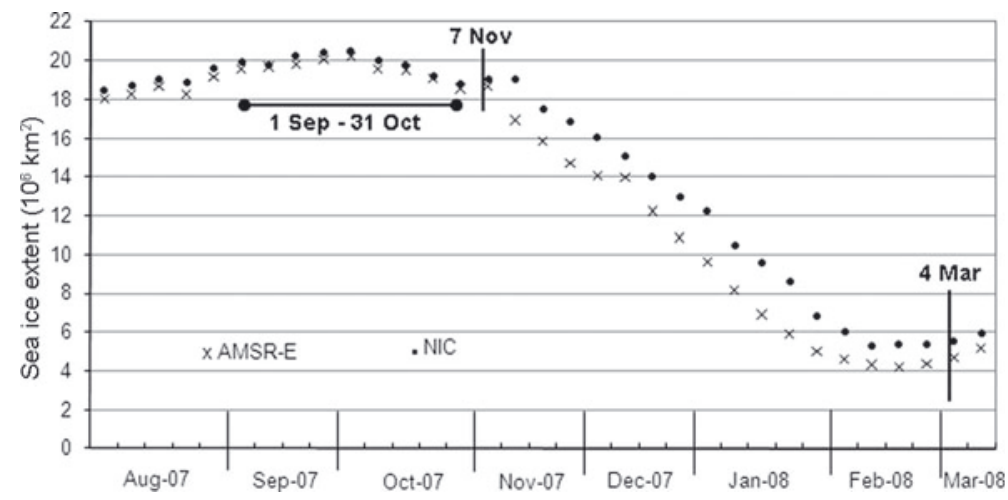

Fig. 2. Antarctic sea-ice extent derived from 2007-08 NIC and AMSR-E (with NT2 algorithm). The SIMBA and SIPEX cruise period is marked (1 September-31 October). 7 November is the date when NIC data start to show a different (greater) extent than AMSR-E. 4 March is when the ice extent starts increasing again. The NIC and AMSR-E comparison is shown for 33 days, sampled weekly (e.g. 1, 8 and 15 August).

downloaded from http://nsidc.org/. Data were imported directly to the HDF-EOS GIS Format Conversion Tool (HEG) and were georeferenced and saved with polar stereographic coordinates. Georeferenced data were then imported to ENVI image-processing software. The total number of pixels of the AMSR-E product includes open water, missing data, land, and sea ice. Using the ENVI software, regions of interest were defined using threshold criteria to obtain only sea-ice concentration between $1 \%$ and $100 \%$. The statistics for sea ice were computed to obtain the pixel numbers that had ice in them for each day. These statistics were imported to an Excel spreadsheet for further analysis. The total number of pixels was multiplied by the pixel size $(12.5 \mathrm{~km} \times 12.5 \mathrm{~km})$ to calculate the sea-ice extent $\left(\mathrm{km}^{2}\right)$ for each day. Additionally, AMSR-E sea-ice concentration products provided by both NT2 and BBA were processed for the days when the in situ observations were collected by observers between 24 and 27 September 2007 and between 24 and 27 October 2007 for the SIMBA cruise. AMSR-E sea-ice concentration products coinciding with the SIPEX cruise, for both NT2 and BBA, were similarly processed between 9 September and 11 October 2007. As explained above, image processing was conducted for the corresponding value of the sea-ice concentration between each individual ASPeCt observation and each AMSR-E pixel value $(12.5 \mathrm{~km} \times 12.5 \mathrm{~km})$ for the same location and day.

\section{National Ice Center (NIC) daily ice edge}

The daily ice-edge products were obtained from NIC. NIC produced ice charts mostly using satellite imagery prior to 1981 (Ozsoy-Cicek and others, 2009). In the 1970s, ice charts were produced by analysts who had to make educated guesses based on climatology or persistence. From 1972 through 1979, only total concentration and ice extent were recorded, relying heavily on visible, infrared and, in particular, single-channel passive microwave imagery (electrically scanning microwave radiometer (ESMR)) launched in 1972. Passive microwave data from scanning multichannel microwave radiometer (SMMR) and Special Sensor Microwave/Imager (SSM/I) were added in 1980 and 1989, respectively. In 1991, NIC began to use Operational Linescan System (OLS) visible and infrared imagery, in 1995 they started using European Remote-sensing Satellite 1 synthetic aperture radar (ERS-1 SAR) at $240 \mathrm{~m}$ resolution, and in 1996 RADARSAT-1 (at 200, 100 and $25 \mathrm{~m}$ resolutions). Quick Scatterometer (QuikSCAT) was added in 2004.
Moderate Resolution Imaging Spectroradiometer (MODIS) and Environmental Satellite (Envisat) advanced SAR (ASAR) Global Monitoring Mode (GMM) were added in 2005. In 2006, NIC, almost exclusively, started using the ESRI-GISbased analysis and production system (Haarpaintner and others, 2004; Nghiem and others, 2006). In 2009, RADARSAT-2 was added. Other data, such as shore-station, ship and buoy reports, aerial reconnaissance, meteorological products, ice-prediction model output, climatology and sea-ice information obtained from foreign ice services, have been used as supplemental information (Godin, 1981), but satellites provided approximately $90 \%$ of the data for the Antarctic (www.natice.noaa.gov).

Presently, NIC provides daily ice-edge data constructed by NIC analysts using all available satellite products listed above. NIC ice analysts provide the necessary value-added interpretation of these imagery sources, with resolutions ranging from $50 \mathrm{~m}$ to $25 \mathrm{~km}$, to properly adjust the extent of the ice-edge contours. In this study, the NIC ice-edge product was acquired from www.natice.noaa.gov for the 2007 winter period and the 2008 summer period to look at the total sea-ice cover before, during and after the SIMBA and SIPEX cruises and also to compare with AMSR-E for the same time period. NIC daily ice edge is provided in an ArcGIS shape file format. Therefore, daily NIC data were directly processed in ArcGIS to obtain the total area of ice cover/extent for dates between 1 August 2007 and 11 March 2008. The NIC data were processed to exclude open-water areas and the large polynyas in the Ross and Amundsen Seas, similar to the AMSR-E ice-cover/-extent determination.

\section{RESULTS AND DISCUSSION}

\section{Sea-ice cover in 2007-08 periods from AMSR-E and NIC}

Figure 2 shows the circumpolar Antarctic sea-ice extent (subsampled weekly from the daily data available) for the period between 1 August 2007 and 11 March 2008 from AMSR-E (NT2) and from NIC. During winter, the figure shows a similar total winter ice extent $\left(18-21 \times 10^{6} \mathrm{~km}^{2}\right)$ from both AMSR-E and NIC, although with the NIC ice extent slightly and consistently larger than the AMSR-E ice extent. The minimum difference between NIC and AMSR-E is on 5 September, when the maximum ice extent occurs. However, for the ice decay season (November-February), 
Table 1. Correlation coefficients $\left(R^{2}\right)$ and root-mean-square difference (rmsd) between sea-ice concentrations from ASPeCt and AMSR-E NT2 and AMSR-E BBA algorithms during SIMBA and SIPEX cruises. MIZ: marginal ice zone

\begin{tabular}{|c|c|c|c|c|c|}
\hline & Observations & $\begin{array}{c}R^{2} \text { between ASPeCt } \\
\text { and NT2 }\end{array}$ & $\begin{array}{c}R^{2} \text { between ASPeCt } \\
\text { and BBA }\end{array}$ & $\begin{array}{c}\text { rmsd between ASPeCt } \\
\text { and NT2 }\end{array}$ & $\begin{array}{c}\text { rmsd between ASPeCt } \\
\text { and BBA }\end{array}$ \\
\hline SIMBA MIZ & 29 & 0.56 & 0.55 & 0.27 & 0.29 \\
\hline SIMBA inner pack & 82 & & & 0.05 & 0.06 \\
\hline SIPEX all & 273 & 0.57 & 0.53 & 0.13 & 0.13 \\
\hline SIPEX inner pack & 244 & & & 0.11 & 0.11 \\
\hline
\end{tabular}

the difference is larger, with $1-2 \times 10^{6} \mathrm{~km}^{2}$ less ice area determined from AMSR-E. The maximum difference is in November, while the minimum difference between NIC and AMSR-E during the summer period occurs in February, when the minimum extent also occurs. The minimum sea-ice extent from AMSR-E is $4 \times 10^{6} \mathrm{~km}^{2}$, while the minimum seaice extent from NIC is $5.4 \times 10^{6} \mathrm{~km}^{2}$. Summer sea ice is normally characterized by ice bands separated by open water and overall lower ice concentrations. During this period, pack ice decays quickly both at the marginal ice zone and in the inner pack-ice zone. As sea ice becomes saturated with sea water, the passive microwave signature of the surface also suggests a lower concentration and tends to result in reduced extent estimates in these sea-water dominated regions. We attribute the difference between ice-edge product and passive microwave primarily to the poorer resolution of wet surfaces by passive microwave during summer, which gives an open-water appearance to the ice edge, as also suggested by Worby and Comiso (2004).

The ASPeCt ship-based observations of the ice edge during winter have compared well with AMSR-E values as reported by Worby and Comiso (2004) and Knuth and Ackley (2006). However, while the contemporaneous ASPeCt ship-based observations of the ice edge during summer compared well with NIC values, these observations do not compare well with AMSR-E as reported by Ozsoy-Cicek and others (2009). For 2006, they found that the total sea-ice-covered area is underestimated by between $0.7 \times 10^{6} \mathrm{~km}^{2}$ and $1.5 \times 10^{6} \mathrm{~km}^{2}$ by AMSR-E compared with NIC ice-edge data. We also found large differences between AMSR-E and NIC ice-edge data in summer that we compute here for a different year. The advantage of NIC data is that the sea-ice extent is apparently better resolved when combining data from different sensors with different temporal and spatial resolutions (from low to high) and with less sensitivity to wet surfaces than passive microwave alone with low spatial resolution. It should also be considered that the marginal ice zone is best studied using high-resolution visible and infrared data. NIC uses these data to derive an ice-edge product that is more sensitive in the marginal ice zone than AMSR-E. Most of the AMSR-E underestimate comes from the marginal ice zone, especially during summer.

\section{Comparison of sea-ice concentration from AMSR-E and SIMBA ASPeCt observations}

Overall correlation between AMSR-E NT2 sea-ice concentration and SIMBA ASPeCt observations (111 pairs) gives $R^{2}=0.80$, which is similar to the 0.77 between AMSR-E BBA sea-ice concentration and ASPeCt observations (Table 1).
The mean ice-concentration values from the SIMBA cruise for 111 observations are $89 \%$ for ASPeCt, $88 \%$ for NT2 and $84 \%$ for BBA. Figure 3 shows the ice concentrations from SIMBA ship-based observations and corresponding AMSR-E (NT2) measurements for the marginal ice zone for 29 observations (Fig. 3a) and for the inner pack-ice zone for 82 observations (Fig. 3b). Clearly, there is good agreement between ASPeCt and AMSR-E in the inner pack-ice zone (Fig. 3b), while the correlation between them is much less $\left(R^{2}=0.56\right.$; Table 1) in the marginal ice zone. Out of 82 observations in the inner ice pack, 67 show AMSR-E NT2 concentration as $100 \%$ and also ASPeCt concentration as $100 \%$; 15 show AMSR-E NT2 concentration as 100\% and ASPeCt concentration $<100 \%$. This probably means that small leads seen along the ship track are not detectable in the AMSR-E pixel of $12.5 \mathrm{~km}$.

As the ship travelled through the ice edge during the beginning of the inbound track, newly formed frazil and brash ice were the dominant ice types with low ice concentrations (observations between 1 and 11 in Fig. 3a). On the outbound track (ASPeCt observations between 12 and 29 in Fig. 3a), nilas began forming, but toward the edge brash or frazil ice was observed predominantly, which formed in leads between smaller floes. As the ship left the ice edge on 27 October 2007, an abrupt change occurred from a high ice concentration of pancake ice $(\sim 25 \mathrm{~cm}$ in size) to $100 \%$ open water. The mean sea-ice concentration in the marginal ice zone for the SIMBA cruise is $64 \%$. The corresponding AMSR-E NT2 and BBA mean sea-ice concentrations for the same marginal ice zone are $54 \%$ and $46 \%$, respectively. Correlations between ASPeCt observations and AMSR-E NT2- and AMSR-E BBA-derived sea-ice concentration are $R^{2}=0.56$ and $R^{2}=0.55$, respectively (Table 1 ). Root-mean-square difference (rmsd) of ice concentration is 0.27 between ASPeCt and NT2 and 0.29 between ASPeCt and BBA for the marginal ice zone. These values are five times higher than the rmsd values (0.05 and 0.06) from the inner pack. Consequently, comparison of the ship observations and passive microwave within the marginal ice zone shows poor agreement. Since the ice edge includes the thin ice types and also ice is mobile around the edge, AMSR-E cannot distinguish reliably areas of low ice concentration from open water.

In the inner pack-ice zone, observations between 1 and 41 are from the inbound track and between 42 and 82 are from the outbound track (Fig. 3b). The primary ice type was highly concentrated first- and multi-year ice. In the transition zone after ice stations on the ASPeCt outbound track (observations starting from 42), large or vast floes eventually 


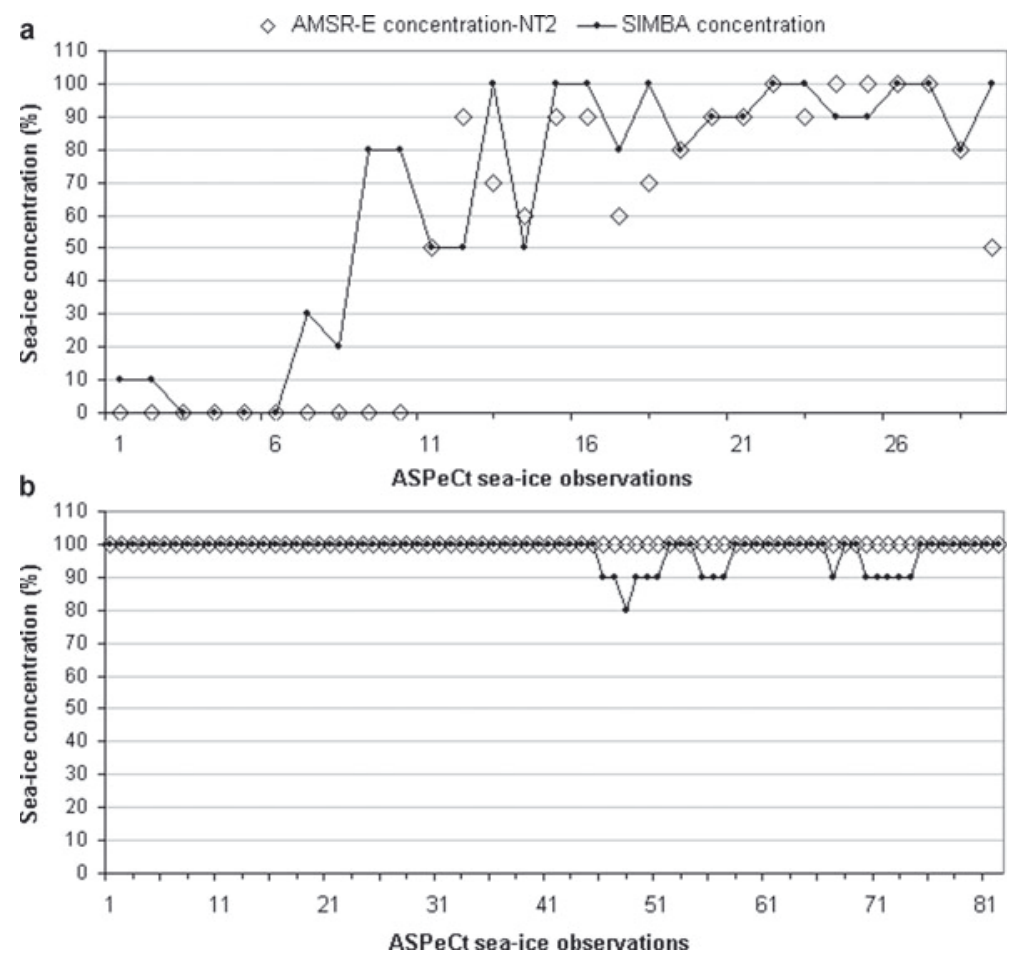

Fig. 3. Paired 111 ASPeCt and AMSR-E sea-ice concentrations during the SIMBA cruise with (a) 29 pairs in the marginal ice zone during inbound and outbound tracks (first 11 observations in the inbound track and last 18 observations in the outbound track; see Fig. 1) and (b) 82 pairs in the inner pack-ice zone during inbound and outbound tracks (the first inner pack observation, number 12, is renumbered from 1 for the inner pack ice in (b)).

became smaller and thinner as pancake ice was broken up by swells or compacted with wind drift. As the ship approached Peter I Island, the first-year ice ended and pancake ice became more dominant (observations starting from 66). The ASPeCt observations gave a mean sea-ice concentration of $98 \%$ in the inner pack-ice zone. NT2- and BBA-derived mean sea-ice concentrations just for the inner pack ice are $100 \%$ and $98 \%$, respectively.

\section{Comparison of sea-ice concentration from AMSR-E and SIPEX ASPeCt observations}

Overall correlation between AMSR-E NT2 sea-ice concentration and ASPeCt observations (273 pairs) gives $R^{2}=0.57$, which is similar to the 0.53 between AMSR-E BBA sea-ice concentration and ASPeCt observations (Table 1). The mean ice-concentration values for all 273 observations of the SIPEX cruise are $90 \%$ for ASPeCt, 95\% for NT2 and 90\% for BBA. Figure 4 shows the ice concentrations from SIPEX observations and corresponding AMSR-E (NT2) measurements for the marginal ice zone for 29 observations (Fig. 4a) and for the inner pack-ice zone for 244 observations (Fig. 4b). Out of 244 observations in the inner ice pack, 147 show AMSR-E NT2 concentration as $100 \%$ and also ASPeCt concentration as $100 \%$; 83 show AMSR-E NT2 concentration as $100 \%$ and ASPeCt concentration $<100 \%$. Only 14 observations show AMSR-E NT2 concentration as $<100 \%$, with 7 showing ASPeCt concentration of $100 \%$ and 7 with ASPeCt concentration $<100 \%$. The better agreement between ASPeCt and the AMSR-E concentration in the inner pack is not as clear for the SIPEX cruise as it is for the SIMBA cruise, but is shown by the lowering of the rmsd concentration value from 0.23 in the marginal ice zone to 0.11 in the inner pack for the SIPEX cruise (Table 1).
The ship traveled through the ice edge, and first observations were conducted on 9 September. Sea-ice observations on the first 2 days were dominated by newly formed frazil, grease and pancake ice with low ice concentrations. For the observation numbers starting at 10 in Figure 4a on 10 October, the ship was about 60 miles from the northern edge of the sea ice on its outbound leg. Young grey-white ice was observed at this point. Variability of sea-ice concentration also increased when the ship was closer to the ice edge. On 11 October at $1300 \mathrm{~h}$ the ship reached the outer edge of the marginal ice zone. The mean sea-ice concentration in the marginal ice zone of the SIPEX cruise is $54 \%$ from ASPeCt observations. The corresponding AMSR-E NT2 and BBA mean sea-ice concentrations for the same marginal ice zone are 58\% and 53\%, respectively. Correlations between ASPeCt observations and AMSR-E NT2- and AMSR-E BBA-derived sea-ice concentration are $R^{2}=0.56$ and $R^{2}=0.55$, respectively (Table 1 ). The rmsd of ice concentration is 0.23 between ASPeCt and NT2 and 0.22 between ASPeCt and BBA for the marginal ice zone. These values are over two times higher than from the inner pack (0.11 and 0.11). Since the end of the cruise period coincided with the end of the growth season (March-October), sea-ice concentration at the ice edge can show extreme variability on both the small scale $(1 \mathrm{~km})$, as observed from the ship, and also on the large scale, as measured by AMSR-E $(12.5 \mathrm{~km})$. In this case, however, AMSR-E concentrations are overestimated compared with ship values.

In the inner pack-ice zone (observations starting at 1 in Fig. 4b), sea-ice concentration increased abruptly and the ice type changed to first-year ice at $-68^{\circ} 23^{\prime} \mathrm{S}, 128^{\circ} 01^{\prime} \mathrm{E}$. Highly concentrated first-year ice was observed until 15 September (until observation 43) when a storm passed during the night. 


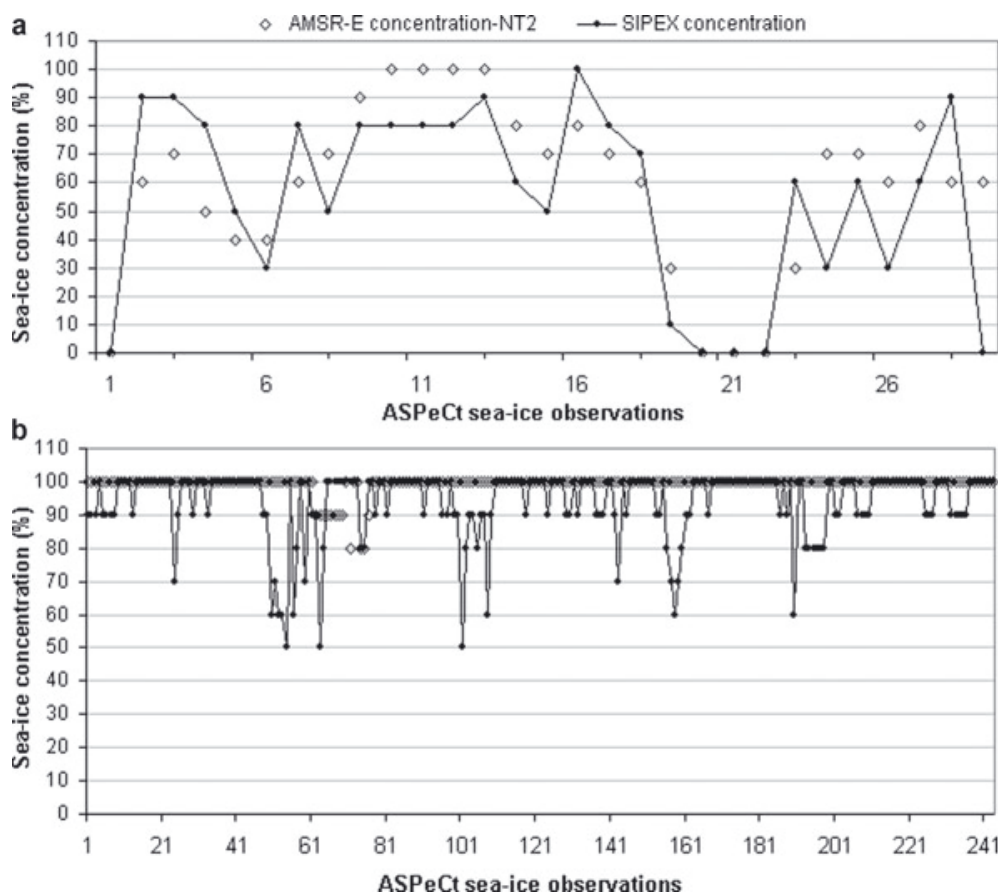

Fig. 4. Paired 273 ASPeCt and AMSR-E sea-ice concentrations during the SIPEX cruise with (a) 29 pairs in the marginal ice zone (first 9 observations and last 20 observations; see Fig. 1) and (b) 244 pairs in the inner pack-ice zone (the first inner pack observation, number 10, is renumbered from 1 for the inner pack ice in (b)).

The storm generated a large swell through the ice, breaking up much of the ice around the ship. Observations between 43 and 60 indicate lower sea-ice concentration because of the broken ice floes created by the storm. The next low ice concentration was observed during 22 September (observations starting at 97 and ending at 113). During 20 and 21 September, a large ocean swell passed through the area where the ship was subsequently located on 22 September. This swell fragmented the ice pack, leaving floes generally $<100 \mathrm{~m}$ across. The swell reduced the sea-ice concentration from $100 \%$ to $50 \%$. Even with the concentration decrease, the dominant sea-ice type was still first-year ice. Figure $4 \mathrm{~b}$ indicates low sea-ice concentration values also between observations 155 and 162. During that period on 29 September, the ship was moving quickly and easily toward the northeast through a series of leads, trying to reach a suitable spot for an ice station for the next day. A further period of low ice concentration is seen between observations 188 and 206. These observations were conducted between 5 and 8 October. Limited observations were made because the ship was at the station on 5-7 October (ice station 13); however, the ship headed north through a series of leads and thin ice floes on 8 October.

The ASPeCt observations during SIPEX show a mean seaice concentration of $94 \%$ in the inner pack-ice zone. NT2and BBA-derived mean sea-ice concentrations for the inner pack ice are $99 \%$ and $94 \%$, respectively. Comparison of the ship observations and passive microwave in the inner packice zone during SIPEX shows a larger range of results and clear seasonal effects compared with SIMBA.

\section{Limitations for ASPeCt observations and AMSR-E data}

Ship-based ASPeCt observations are collected while the ship navigates and penetrates through the sea ice. One significant bias often raised is that ASPeCt observations occur in thin ice due to the pilot's navigational desire to avoid thick ice.
Ideally, ship tracks are predefined straight lines through the pack. However, the ship tracks depend on the project and purpose of the work. During the SIMBA cruise, the ship penetrated the marginal ice zone and the heavy sea-ice pack on the western part of Antarctica generally along straight-line tracks. However, during the SIPEX cruise, the ship navigated to take advantage of weaker ice conditions both in the marginal ice zone and the inner pack-ice zone. In addition, swell penetrated intermittently but deeply into the interior pack ice in East Antarctica, giving an intermittent marginal ice zone character for much of the ice cover there. These two factors help explain the difference between the inner packice zones during the two cruises shown in Figures $3 \mathrm{~b}$ and $4 \mathrm{~b}$ where bias is created by: (1) navigation routing differences; and (2) different pack-ice characteristics of the regions.

Another difference between ASPeCt observations and satellite-retrieved sea-ice concentration in Figures $3 \mathrm{~b}$ and $4 \mathrm{~b}$ is created by the size of the ASPeCt ship-based observed area compared with the satellite footprint size. For the SIMBA cruise, datasets show agreement for the interior portion of the observations in Figure $3 \mathrm{~b}$. However, for the SIPEX cruise, it is seen in Figure $4 \mathrm{~b}$ that the bias is exacerbated since the ship navigated through the marginal ice zone and the intermittent marginal ice zone for better travelling conditions. The thin ice cover observed within a $1 \mathrm{~km}$ radius may therefore be less representative of a satellite pixel for the SIPEX cruise than the SIMBA cruise.

\section{CONCLUSION}

The ASPeCt ship-based sea-ice observations conducted on the IPY 2007 SIMBA and SIPEX cruises were used to validate sea-ice concentration derived from simultaneous passive microwave remote-sensing data. Overall, the NT2 algorithm ice concentrations are greater than the BBA ice concentrations. Ice concentration derived from NT2 indicates only 
slightly higher correlation with ASPeCt-observed sea-ice concentrations than the correlation between the ice concentrations derived from BBA and ASPeCt observations.

The position of the ice edge, albeit from a total of only four ice-edge crossings for the two cruises, showed the closer winter correspondence between ship-observed ice edge and passive microwave, as observed previously (Worby and Comiso 2004). Comparison of the NIC ice-edge data and passive microwave data overall also showed similar areas inside the ice edge during winter, in agreement with these limited observations. Large-scale summer deviation between the NIC ice-chart area and passive microwave estimates apparently occurs due to the poorer resolution of the microwave in warmer and lower-concentration ice conditions. This behavior was also observed in a few instances in the winter cruises in the outer ice edges where new ice formation and low concentrations were observed. For the interior portions of the winter ice in the SIMBA region $\left(\sim 90^{\circ} \mathrm{W}\right)$, good agreement (only $0.05 \mathrm{rmsd}$ ) was seen between AMSR-E ice concentration and ASPeCt observations at near $100 \%$ concentration, five times lower compared with a rmsd of 0.26 in the marginal ice zone. However, for the SIPEX region, large swell events that broke up the ice cover and created lower-concentration conditions and/or smaller floes contributed to an intermittent marginal ice zone character of the entire ice cover there. These characteristics also apparently contributed to a poorer correspondence between ship-based concentration estimates and AMSR-E values with both lower $R^{2}=0.56$ (derived from NT2) and only a twofold difference in rmsd between the marginal ice zone (0.23) and the rmsd in the SIPEX inner pack region (0.11). The intermittent marginal ice zone behavior also accounts for the doubling of the inner pack rmsd for the SIPEX region (0.11), not seen in the uniformly highly compacted conditions in the SIMBA region (0.05) in West Antarctica.

In conclusion, this paper shows that the ASPeCt shipbased observations complement the satellite retrievals, but also indicate areas where the satellite retrieval algorithms could be improved.

\section{ACKNOWLEDGEMENTS}

We acknowledge the US National Science Foundation (NSF) grant AWT0703682 and NASA grant NNX08AQ87G (principal investigator: S.F. Ackley) and Australian Antarctic Division support (A.W. and J.L.) for allowing us to conduct cruises during the IPY activities; the US National Snow and Ice Data Center in Boulder, CO, for providing us with AMSR-E images; and the US National Ice Center for providing the ice chart data. The International Space Science Institute (Bern, Switzerland) is acknowledged for supporting this study via projects 137, 169 and 184. We thank the scientific editor and two anonymous reviewers for giving us good support to improve our paper. We also thank the SIMBA and SIPEX crews for their assistance during the cruises. Special thanks go to the ASPeCt observers for their valuable efforts.

\section{REFERENCES}

Brandt, R.E., S.G. Warren, A.P. Worby and T.C. Grenfell. 2005. Surface albedo of the Antarctic sea ice zone. J. Climate, 18(17), 3606-3622.
Cavalieri, D.J. and C.L. Parkinson. 2008. Antarctic sea ice variability and trends, 1979-2006. J. Geophys. Res., 113(C7), C07004. (10.1029/2007JC004564.)

Cavalieri, D.J., C.L. Parkinson and K.Y. Vinnikov. 2003. 30-Year satellite record reveals contrasting Arctic and Antarctic decadal sea ice variability. Geophys. Res. Lett., 30(18), 1970. (10.1029/ 2003GL018031.)

Comiso, J.C. 1995. SSM/I sea ice concentrations using the Bootstrap algorithm. NASA Ref. Publ. 1380.

Comiso, J.C., T.C. Grenfell, M. Lange, A.W. Lohanick, R.K. Moore and P. Wadhams. 1992. Microwave remote sensing of the Southern Ocean ice cover. Passive microwave signatures of sea ice. In Carsey, F.D. and 7 others, eds. Microwave remote sensing of sea ice. Washington, DC, American Geophysical Union, 243-259. (Geophysical Monograph Series 68.)

Comiso, J.C., D.J. Cavalieri and T. Markus. 2003. Sea ice concentration, ice temperature, and snow depth using AMSR-E data. IEEE Trans. Geosci. Remote Sens., 41(2), 243-252.

Gloersen, P., W.J. Campbell, D.J. Cavalieri, J.C. Comiso, C.L. Parkinson and H.J. Zwally. 1992. Arctic and Antarctic sea ice, 1978-1987: satellite passive-microwave observations and analysis. NASA Tech. Rep. SP-511.

Godin, R.H. 1981. Sea ice charts of the Navy/NOAA Joint Ice Center. Glaciol. Data, World Data Center A for Glaciol. GD-11, 71-77.

Haarpaintner, J., R.T. Tonboe, D.G. Long and M.L. van Woert. 2004. Automatic detection and validity of the sea-ice edge: an application of enhanced-resolution QuikScat/SeaWinds data. IEEE Trans. Geosci. Remote Sens., 42(7), 1433-1443.

Knuth, M.A. and S.F. Ackley. 2006. Summer and early-fall sea-ice concentration in the Ross Sea: comparison of in situ ASPeCt observations and satellite passive microwave estimates. Ann. Glaciol., 44, 303-309.

Kwok, R., J.C. Comiso, S. Martin and R. Drucker. 2007. Ross Sea polynyas: response of ice concentration retrievals to large areas of thin ice. J. Geophys. Res., 112(C12), C12012. (10.1029/ 2006JC003967.)

Lewis, M.J. and 6 others. In press. Sea ice and snow cover characteristics during the winter-spring transition in the Bellingshausen Sea: an overview of SIMBA 2007. Deep-Sea Res. II.

Liu, J., J.A. Curry and D.G. Martinson. 2004. Interpretation of recent Antarctic sea ice variability. Geophys. Res. Lett., 31(2), L02205. (10.1029/2003GL018732.)

Lubin, D. and R. Massom. 2006. Polar remote sensing. Volume 1: atmosphere and oceans. Chichester, Springer-Praxis.

Markus, T. and D.J. Cavalieri. 2000. An enhancement of the NASA Team sea ice algorithm. IEEE Trans. Geosci. Remote Sens., 38(3), 1387-1398.

Massom, R.A., J.C. Comiso, A.P. Worby, V.I. Lytle and L. Stock. 1999. Regional classes of sea ice cover in the East Antarctic pack observed from satellite and in situ data during a winter time period. Remote Sens. Environ., 68(1), 61-76.

Nghiem, S.V. and 6 others. 2006. Depletion of perennial sea ice in the East Arctic Ocean. Geophys. Res. Lett., 33(17), L17501. (10.1029/2006GL027198.)

Ozsoy-Cicek, B., H. Xie, S.F. Ackley and K. Ye. 2009. Antarctic summer sea ice concentration and extent: comparison of ODEN 2006 ship observations, satellite passive microwave and NIC sea ice charts. Cryosphere, 3(1), 1-9.

Ozsoy-Cicek, B., S. Kern, S.F. Ackley, H. Xie and A.E. Tekeli. In press. Intercomparisons of Antarctic sea ice types from visual ship, RADARSAT-1SAR, Envisat ASAR, QuikSCAT, and AMSR-E satellite observations in the Bellingshausen Sea. Deep-Sea Res. II. (10.1016/j.dsr2.2010.10.031.)

Parkinson, C.L. and D.J. Cavalieri. 2008. Arctic sea ice variability and trends, 1979-2006. J. Geophys. Res., 113(C7), C07003. (10.1029/2007JC004558.)

Parkinson, C.L. and J.C. Comiso. 2008. Antarctic sea ice parameters from AMSR-E data using two techniques and comparisons with 
sea ice from SSM/I. J. Geophys. Res., 113(C2), C02S06. $(10.1029 / 2007 J C 004253$.

Solomon, S. and 7 others, eds. 2007. Climate change 2007: the physical science basis. Contribution of Working Group I to the Fourth Assessment Report of the Intergovernmental Panel on Climate Change. Cambridge, etc., Cambridge University Press.

Turner, J. and 8 others, eds. 2009. Antarctic climate change and the environment. Cambridge, Scott Polar Research Institute, Scientific Committee on Antarctic Research.

Weissling, B., M.J. Lewis and S.F. Ackley. In press. Sea ice thickness and mass at Ice Station Belgica, Bellingshausen Sea, Antarctica. Deep-Sea Res. II. (10.1016/j.dsr2.2010.10.032.)

Worby, A.P. and I. Allison. 1999. A technique for making shipbased observations of Antarctic sea ice thickness and characteristics. Part I. Observational techniques and results. Antarct. CRC Res. Rep. 14.
Worby, A.P. and J.C. Comiso. 2004. Studies of the Antarctic sea ice edge and ice extent from satellite and ship observations. Remote Sens. Environ., 92(1), 98-111.

Worby, A.P. and 9 others. In press. Regional-scale sea ice and snow thickness distributions from in situ and satellite measurements over East Antarctic pack ice during SIPEX 2007. Deep-Sea Res. II. (10.1016/j.dsr2.2020.10.)

$\mathrm{Xie}, \mathrm{H}$. and 6 others. In press. Sea ice thickness distribution of the Bellingshausen Sea from surface measurement and ICESat altimetry. Deep-Sea Res. II. (10.1016/j.dsr2.2020.10.)

Zhang, J. 2007. Increasing Antarctic sea ice under warming atmospheric and oceanic conditions. J. Climate, 20(11), 2515-2529.

Zwally, H.J., J.C. Comiso, C.L. Parkinson, D.J. Cavalieri and P. Gloersen. 2002. Variability of Antarctic sea ice 1979-1998. J. Geophys. Res., 107(C5, 3041). (10.1029/2000JC000733.) 